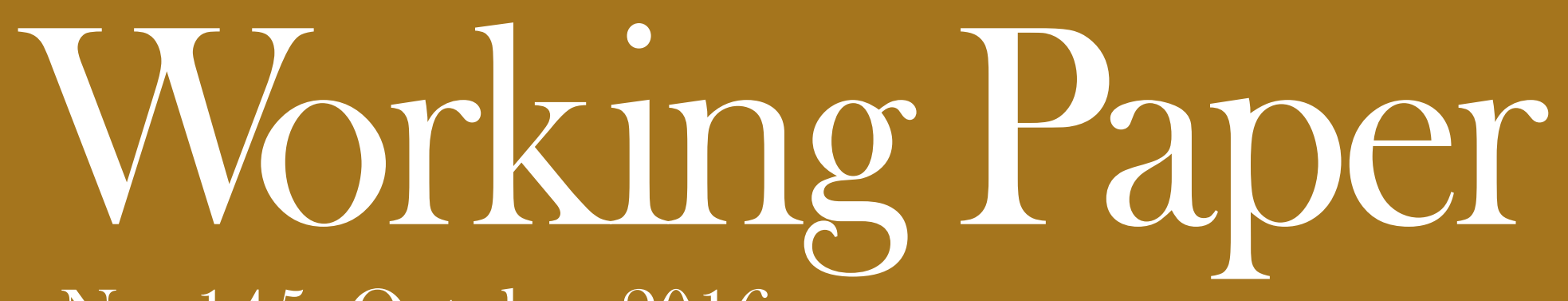

No. 145. October 2016

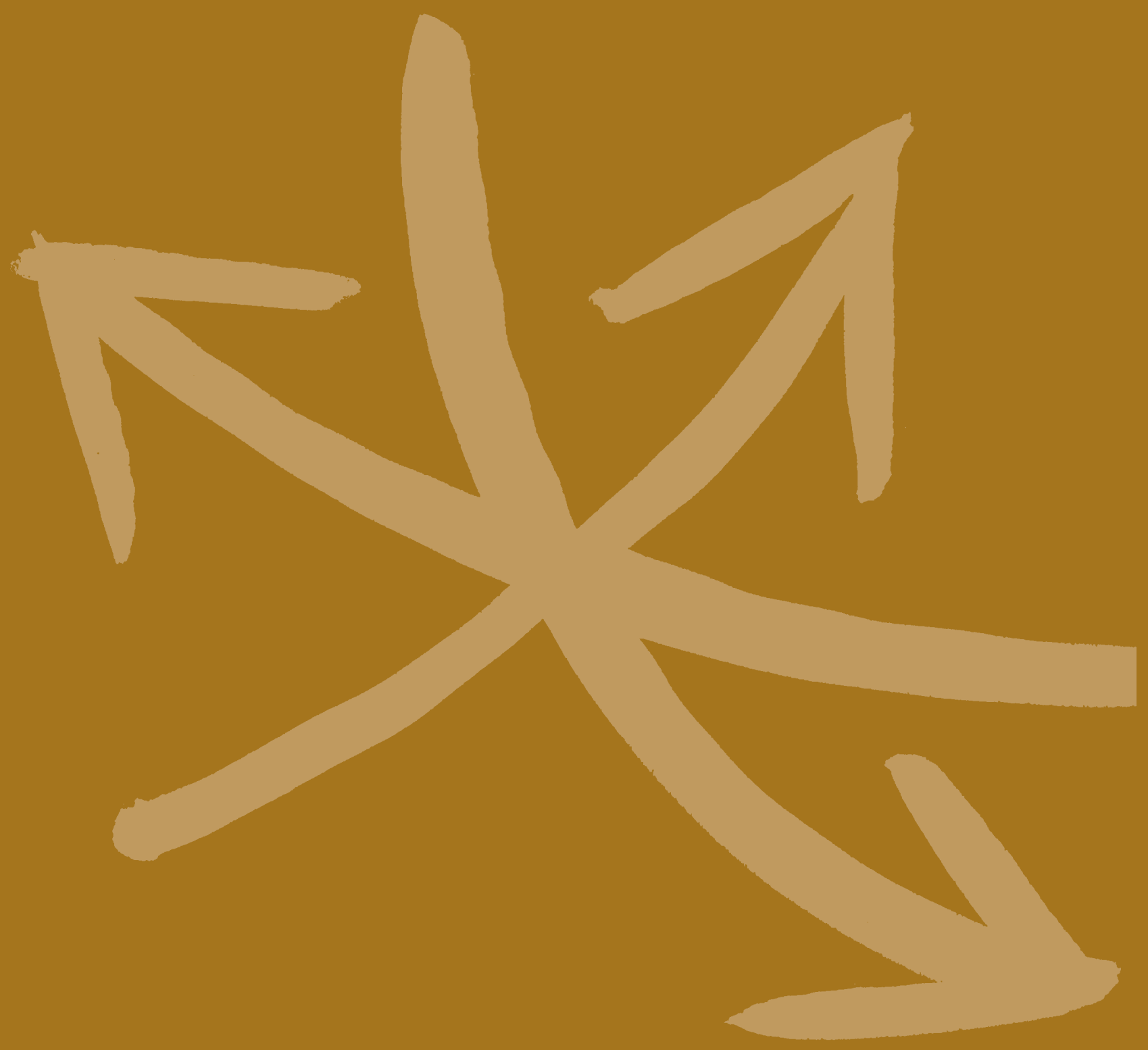

\title{
Do Inflation Expectations Granger Cause Inflation?
}

By Pär Stockhammar and Pär Österholm

National Institute of Economic Research

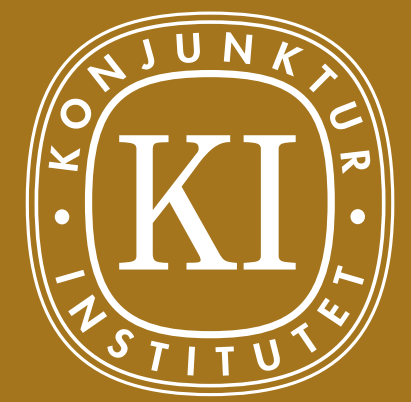





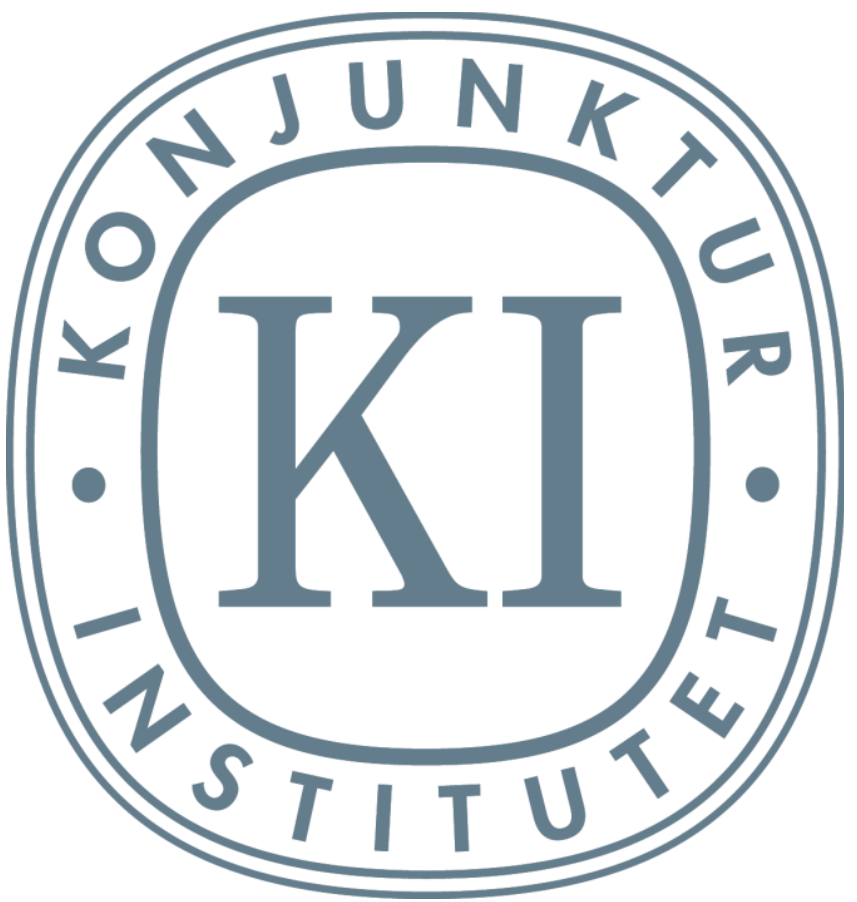

\section{Do Inflation Expectations Granger Cause Inflation?*}

Pär Stockhammar" and Pär Österholm*

October 2016

\footnotetext{
* We are grateful to seminar participants at the National Institute of Economic Research for valuable comments on this paper.

\# National Institute of Economic Research, Box 3116, 10362 Stockholm, Sweden e-mail: par.stockhammar@konj.se Phone: +46 84535910

- Örebro University, School of Business, 70182 Örebro, Sweden e-mail: par.osterholm@oru.se Phone: +46708628986 
NIER prepares analyses and forecasts of the Swedish and international economy and conducts related research. NIER is a government agency accountable to the Ministry of Finance and is financed largely by Swedish government funds. Like other government agencies, NIER has an independent status and is responsible for the assessments that it publishes.

The Working Paper series consists of publications of research reports and other detailed analyses. The reports may concern macroeconomic issues related to the forecasts of the institute, research in environmental economics, or problems of economic and statistical methods. Some of these reports are published in their final form in this series, whereas others are previews of articles that are subsequently published in international scholarly journals under the heading of Reprints.

Reports in both of these series can be ordered free of charge. Most publications can also be downloaded directly from the NIER website. 


\begin{abstract}
In this paper, we investigate whether survey measures of inflation expectations in Sweden Granger cause Swedish CPI-inflation. This is done by studying the precision of out-of-sample forecasts from Bayesian VAR models using a sample of quarterly data from 1996 to 2016. It is found that the inclusion of inflation expectations in the models tends to improve forecast precision. However, the improvement is typically small enough that it could be described as economically irrelevant. One exception can possibly be found in the expectations of businesses in the $\mathrm{Na}$ tional Institute of Economic Research's Economic Tendency Survey; when included in the models, these improve forecast precision in a meaningful way at short horizons. Taken together, it seems that the inflation expectations studied here do not provide a silver bullet for those who try to improve VAR-based forecasts of Swedish inflation. The largest benefits from using these survey expectations may instead perhaps be found among analysts and policy makers; they can after all provide relevant information concerning, for example, the credibility of the inflation target or challenges that the central bank might face when conducting monetary policy.
\end{abstract}

JEL classification code: C32, F43

Keywords: Bayesian VAR, Granger causality, Out-of-sample forecasts 


\section{Sammanfattning}

I denna studie undersöks om enkätbaserade mått på inflationsförväntningar i Sverige Grangerorsakar den svenska KPI-inflationen. Detta görs genom att studera precisionen i "out-of-sample"-prognoser från Bayesianska VARmodeller på kvartalsdata 1996-2016. Införandet av inflationsförväntningarna i modellerna tenderar att förbättra prognosprecisionen. Dock är skillnaden så liten att den oftast kan beskrivas som ekonomiskt irrelevant. Ett undantag utgörs möjligen av företagens inflationsförväntningar i Konjunkturbarometern; när dessa inkluderas i modellerna förbättras prognosprecisionen på korta horisonter i en utsträckning som är relevant. Sammantaget förefaller det inte som om de studerade inflationförväntningarna kan utgöra en silverkula för de som försöker ta fram förbättrade VAR-baserade prognoser för svensk inflation. Möjligen är det istället analytiker och policymakare som huvudsakligen kan dra fördel av inflationsförväntningarna; de kan trots allt ge relevant information rörande till exempel trovärdigheten hos inflationsmålet eller utmaningar som centralbanken kan stå inför vid genomförandet av penningpolitiken. 


\section{Contents}

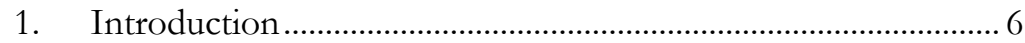

2. Inflation-expectations data .......................................................... 8

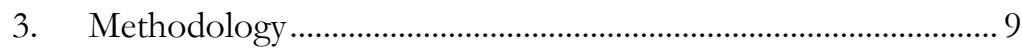

3.1 The Bayesian VAR model........................................................ 10

3.2 Granger causality.............................................................. 11

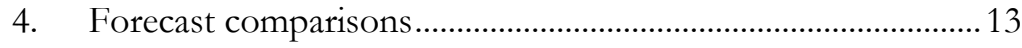

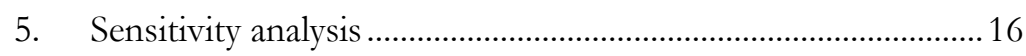

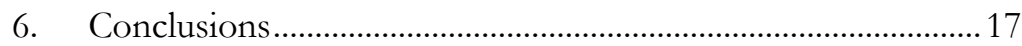

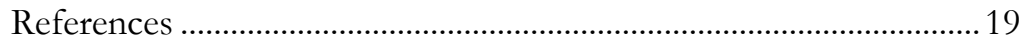

Appendix A - Data ............................................................................. 21

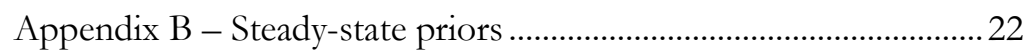

Appendix C - RMSFEs and relative RMSFEs..................................23 


\section{Introduction}

Survey measures of inflation expectations are often given a lot of attention when they are published. There are several reasons for this. For example, in an inflation targeting economy, inflation expectations are considered to provide information about the credibility the central bank's inflation target. Poorly anchored long-run inflation expectations can be interpreted as the inflation target having credibility problems. ${ }^{1}$ One policy implication of this is that if the target is not explicitly stated - or expressed clearly enough - it should be made more transparent. In addition, inflation expectations play a key role as a determinant of future inflation in many widely employed models nowadays. ${ }^{2}$ It is therefore of great importance to investigate if they provide useful information to analysts and forecasters who aim to understand and predict the evolution of inflation.3,4

In this paper, we aim to improve the understanding of how survey measures of inflation expectations relate to future inflation. More specifically, we assess the usefulness of survey measures of inflation expectations in Sweden from a forecast perspective. This is done by investigating whether inflation expectations Granger cause inflation. Inflation expectations are said to Granger cause inflation if they improve the forecast precision relative to a model which does not include inflation expectations. We make use of the state-of-the-art mean-adjusted Bayesian VAR (BVAR) framework of Villani (2009) to conduct an out-of-sample forecast exercise using quarterly data from 1996 to 2016. Two benchmark models without inflation expecta-

\footnotetext{
1 See, for example, Gürkaynak et al. (2007) and Beechey et al. (2011).

2 This includes the New-Keynesian DSGE model, which has become a workhorse within many central banks; see, for example Adolfson et al. (2007) and Christoffel et al. (2011).

3 That inflation expectations actually matter can be exemplified by the fact that the Riksbank rather unnecessarily - raised the policy interest rate in September 2008, partly motivated by high inflation expectations. The Riksbank's governor Stefan Ingves stated that he wanted to "see $a$ reduction in inflation and inflation expectations before easing monetary policy" (Sveriges Riksbank, 2008, p. 18).

4 There is a reasonably large literature looking at the importance of survey expectations of inflation, with varying results. See, for example, Nunes (2010) who generally found a small empirical role for survey expectations in the United States or Adam and Padula (2010) who found survey expectations to be an important factor of inflation in the United Kingdom. Fuhrer (2012) concluded that short-run inflation expectations have a significant role in explaining US inflation since the beginning of the 1980 s, while long-run expectations generally did not have the same direct influence over the same period. Canova and Gambetti (2010) found that one-year ahead inflation expectations consistently had predictive content in the United States 1960-2005. Wimanda et al. (2011) showed that CPI inflation in Indonesia is significantly determined by, especially, backward-looking inflation expectations. Studying VAR estimates, Clark and Davig (2008), found that shocks to short- and long-term inflation expectations result in some passthrough to actual inflation in the United States.
} 
tions are used for our analysis: i) a univariate autoregressive model and ii) a trivariate BVAR model including inflation, the unemployment rate and the three month treasury bill rate. We accordingly study the forecast performance of four model sizes. This is done at forecast horizons from one up to twelve quarters - a reasonable focus given that the ability to predict inflation at short to medium term horizons is what matters to policy makers such as central banks.

Methodologically, this study is close to other papers using out-of-sample forecast performance to assess Granger causality of various variables for inflation; see, for example Bachmeier et al. (2007), Gavin and Kliesen (2008), Berger and Österholm (2011) and Scheufele (2011). It is also related to studies which rely on VARs to investigate the relationship between survey measures of inflation expectations and inflation, such as Clark and Davig (2008) and Canova and Gambetti (2010). We make a number of contributions relative to the previous literature though. First, Sweden was one of the early adopters of inflation targeting when the policy was declared in 1993. It is of general interest to investigate the issue of Granger causality of survey measures of inflation expectations for inflation in this environment. Second, we provide evidence concerning which survey expectations actually have additional information value for Swedish inflation. Third, we conduct the analysis in a framework - the mean-adjusted BVAR of Villani (2009) - which has not previously been used to assess the Granger causality of survey measures of inflation expectations for inflation.

Our results indicate that while inflation expectations might Granger cause Swedish inflation, the quantitative improvement in forecast precision is often small enough to be empirically irrelevant.

The rest of this paper is organised as follows. Section 2 briefly presents the survey data on inflation expectations used for our analysis. The BVAR model and the concept of Granger causality are discussed in Section 3. In Section 4, we present the results from our out-of-sample forecast exercise. We conduct a sensitivity analysis in Section 5. Finally, Section 6 concludes. 


\section{Inflation-expectations data}

We assess the forecasting properties of inflation expectations from Sweden's two main surveys: TNS Sifo Prospera's inflation survey - which is conducted on behalf of the Riksbank - and the Economic Tendency Survey of the National Institute of Economic Research.

TNS Sifo Prospera asks approximately 235 businesses and organisations about their inflation expectations at the one-, two- and five-year horizon four times a year. In the main text, we study the expectations that typically receive the most attention, namely the "overall" inflation expectation for each horizon; this is generated by taking the arithmetic mean over all respondents (by horizon). 5

In the National Institute of Economic Research's Economic Tendency Survey, both households and businesses are asked about their inflation expectations. Approximately 1500 households and 6500 business are interviewed. ${ }^{6}$ Unlike the TNS Sifo Prospera survey though, the respondents are only asked about the one-year-ahead inflation expectation.

All together, we accordingly get five series of inflation expectations. These data are shown in Figure 1, together with CPI inflation, for the sample 1996Q1-2016Q1. CPI inflation is calculated as the year-on-year percentage change in the CPI $\left(P_{t}\right)$, that is, $\pi_{t}=100\left(P_{t} / P_{t-4}-1\right)$.

As can be seen from the figure, the inflation expectations all show roughly the same pattern.7 For example, all five series increased noticeably between 2005 and 2008 in line with the increase in actual inflation during that period. Similarly, a fall in expectations is present in all series following the glob-

\footnotetext{
5 The results from the survey are also available for five other subcategories: money market players, employee organisations, employer organisations, manufacturing companies and trade companies. Money market players are interviewed every month and are generally given most attention in the media. However, this study shows that forecast precision is almost identical when using the inflation expectations of money market players instead of the overall measure; see tables A2, A3, A8 and A9 in Appendix C. Data on the money market players' inflation expectations are displayed in Figure $A 2$ in Appendix A.

6 The households are asked every month and the businesses once every quarter. For the households we use the mean of all respondents after excluding extreme values; monthly values have been converted to quarterly using the arithmetic mean.

7 The correlation between the different categories of inflation expectations varies between 0.63 and 0.98 .
} 
al financial crisis. It can also be noted how inflation expectations have drifted down in the last few years, as the Riksbank has had problems with target achievement. $^{8}$

\section{Figure 1. Data.}
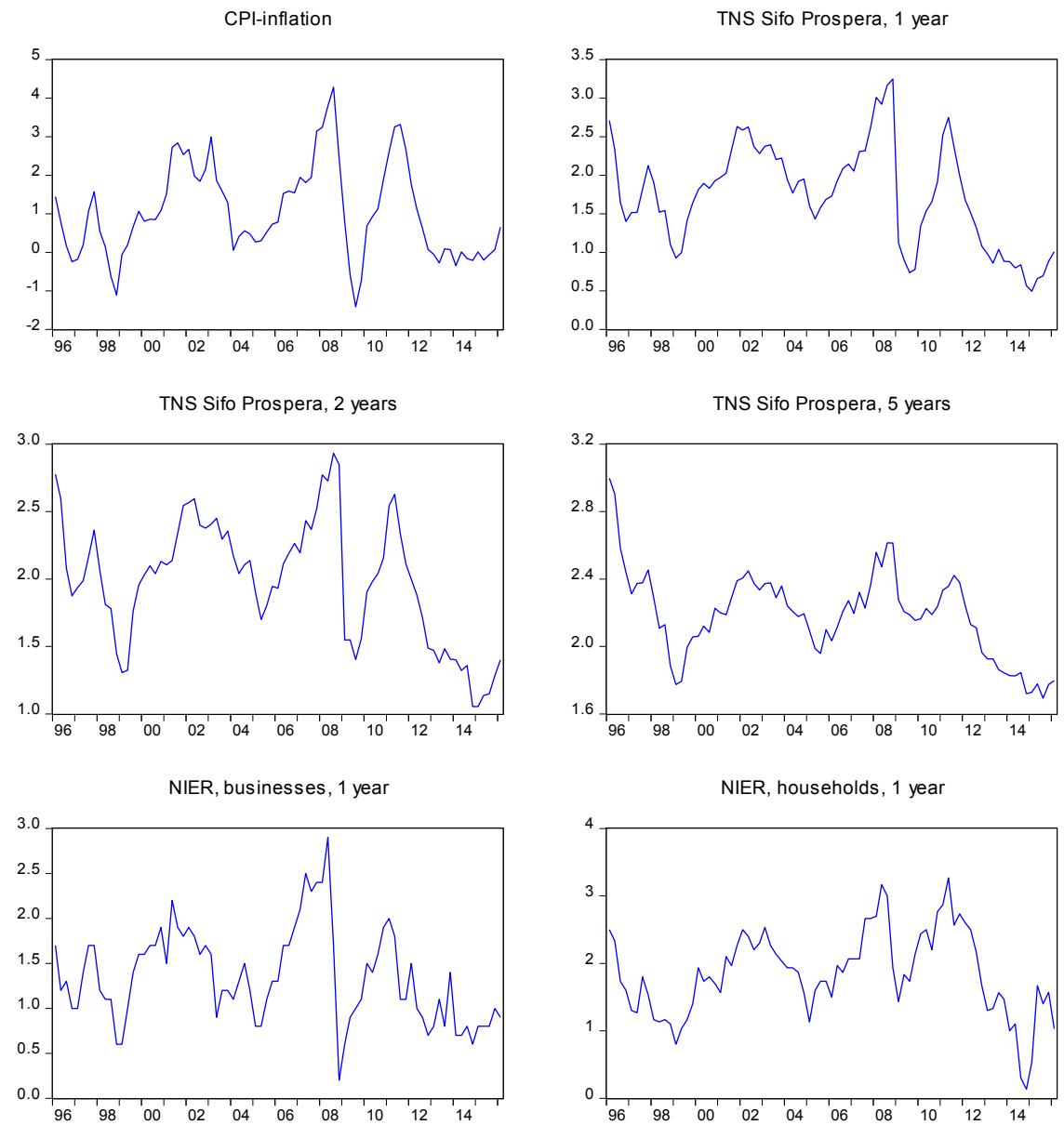

Note: All variables are measured in per cent. The inflation expectation series of households in the NIER survey have been converted from monthly to quarterly data using the arithmetic mean.

\section{Methodology}

There are different ways to assess whether inflation expectations have predictive power for inflation. In this paper, we primarily rely on an out-ofsample forecast exercise using a BVAR model. 9 In this section, we first

${ }^{8}$ For a discussion about the problems associated with the anchoring of inflation expectations; see, for example, Beechey et al. (2011).

9 In the sensitivity analysis presented in Section 5, we also use VAR models estimated with classical methods. 
present the model and then discuss the issue of establishing Granger causality in an out-of-sample framework.

\subsection{The Bayesian VAR model}

We use the Bayesian VAR model given by

$$
\mathbf{G}(L)\left(\mathbf{x}_{t}-\boldsymbol{\mu}\right)=\boldsymbol{\eta}_{t},
$$

as the main tool for our analysis. As can be seen from equation (1), the model is expressed in deviations from its steady state. This feature was introduced by Villani (2009) and has the benefit that an informative prior distribution for the steady-state values of the variables in the system - the $n \times 1$ vector $\boldsymbol{\mu}$ - can be specified. Obviously, this can be particularly useful when forecasting Swedish inflation seeing that the Riksbank has an explicitly stated inflation target. ${ }^{10}$

The rest of the model is defined as follows: $\mathbf{G}(L)=\mathbf{I}-\mathbf{G}_{1} L-\ldots-\mathbf{G}_{m} L^{m}$ is a lag polynomial of order $m$; the lag length of the model is in all cases set to $m=4 . \mathbf{x}_{t}$ is an $n \times 1$ vector of stationary variables and $\boldsymbol{\eta}_{t}$ is an $n \times 1$ vector of ïd error terms fulfilling $E\left(\boldsymbol{\eta}_{t}\right)=\mathbf{0}$ and $E\left(\boldsymbol{\eta}_{t} \boldsymbol{\eta}_{t}^{\prime}\right)=\boldsymbol{\Sigma}$.

The priors of the model largely follow convention in the literature. For $\boldsymbol{\Sigma}$ the prior is given by $p(\boldsymbol{\Sigma}) \propto|\boldsymbol{\Sigma}|^{-(n+1) / 2}$ and the prior on $\operatorname{vec}(\mathbf{G})$, where $\mathbf{G}=\left(\begin{array}{lll}\mathbf{G}_{1} & \ldots & \mathbf{G}_{m}\end{array}\right)^{\prime}$, is given by $\operatorname{vec}(\mathbf{G}) \sim N_{m n^{2}}\left(\boldsymbol{\theta}_{\mathbf{G}}, \boldsymbol{\Omega}_{\mathbf{G}}\right)$. It can be noted that the priors on the dynamics have been modified somewhat relative to the traditional Minnesota prior; this is standard when using Villani's specification. ${ }^{11}$ The prior on $\boldsymbol{\mu}$ is given by $\boldsymbol{\mu} \sim N_{n}\left(\boldsymbol{\theta}_{\boldsymbol{\mu}}, \boldsymbol{\Omega}_{\boldsymbol{\mu}}\right)$ and is specified in detail in Table A1 in Appendix B. The hyperparameters of the model are also in line

\footnotetext{
10 Villani's specification of the BVAR can improve forcast accuracy when it comes to inflation. This has been shown by, for example, Beechey and Österholm (2010).

11 The prior mean on the first own lag for each variable is here set equal to 0.9 and all other coefficients in $\mathbf{G}$ have a prior mean of zero.
} 
with mainstream choices in the literature: We set the overall tightness to 0.2 , the cross-variable tightness to 0.5 and the lag decay parameter to 1 .

\subsection{Granger causality}

In this paper, we are interested in whether inflation expectations have predictive power for CPI inflation. If inflation expectations contain information which is useful when forecasting CPI inflation that is not found in other variables, we conclude that inflation expectations Granger cause CPI inflation.

Granger causality can be analysed both within sample and out-of-sample. We choose to assess Granger causality out-of-sample rather than within sample. ${ }^{12}$ There are several reasons for choosing this approach. First, it is closer to Granger's original idea and it can be noted that evaluating out-ofsample forecast performance was called the "sound and natural approach" to establish Granger-causality by Ashley et al. (1980, p. 1149). Second, out-ofsample forecasts are also convenient to use since within-sample tests are difficult to implement in a multivariate framework. ${ }^{33}$ Finally, out-of-sample forecast performance presents a higher hurdle than within-sample tests, given the well-known tendency for overfitting models when relying on within-sample analysis.

In this setting, Granger causality requires that the out-of-sample forecast performance of a BVAR model including inflation expectations is better than that of an otherwise identical model excluding inflation expectations. We will make two comparisons here. The first is between a univariate model of CPI inflation and a bivariate model with CPI inflation and inflation expectations. In this case, we define the vector $\mathbf{x}_{t}$ in equation (1) as

\footnotetext{
12 Within-sample Granger causality tests have been employed by, for example, Stock and Watson (1989), Friedman and Kuttner (1993) and Us (2004).

13 It is easy to test for Granger causality within-sample in a bivariate framwork. For example, if lags of inflation expectations were found to be non-zero in a regression of CPI inflation on its own lags and lags of inflation expectations, we would conclude that inflation expectations Granger cause CPI inflation. However, when the number of variables is larger than two and the forecasting horizon is larger than one period, it becomes more complicated; see, for example, Lütkepohl (2005) for a discussion.
} 
$\mathbf{x}_{t}=\left(\pi_{t}\right)$

in the univariate case and

$\mathbf{x}_{t}=\left(\begin{array}{ll}\pi_{t} & \pi_{t}^{e}\end{array}\right)^{\prime}$

in the bivariate case, where $\pi_{t}$ is CPI inflation as defined above and $\pi_{t}^{e}$ is an inflation expectation series. If the root mean square forecast error (RMSFE) of the bivariate model is lower than that of the univariate model at a given horizon, we conclude that inflation expectations Granger cause CPI inflation at this horizon. Non-causality is present if the forecasting performance of the bivariate model is worse than that of the univariate model.

The second comparison we take into account other, potentially important, variables. This is done using a trivariate model with CPI-inflation, the unemployment rate and the three month treasury bill rate

$\mathbf{x}_{t}=\left(\begin{array}{lll}u_{t} & \pi_{t} & i_{t}\end{array}\right)^{\prime}$

and a model with four variables defined as

$\mathbf{x}_{t}=\left(\begin{array}{llll}u_{t} & \pi_{t} & i_{t} & \pi_{t}^{e}\end{array}\right)^{\prime}$,

where $u_{t}$ is the unemployment rate in the age group 15-74 years (seasonally adjusted using Tramo/Seats), $i_{t}$ is the three month treasury bill rate and $\pi_{t}$ and $\pi_{t}^{e}$ are defined as above. The trivariate specification seems like a reasonable benchmark for a "larger" model. Trivariate VARs with these variables are commonly used in the macroeconomic literature; see, for example, Cogley and Sargent (2001), Primiceri (2005) and Ribba (2006).

We focus on the RMSFE of the models and do not conduct any hypothesis tests regarding the forecast precision. We argue that this is a reasonable ap- 
proach when evaluating the addition of a variable to a model. ${ }^{14}$ When the purpose of the model purely is forecasting, the forecaster would - in the choice between two models that are considered equally likely a priori - generally choose the model with the smallest RMSFE. 15

\section{Forecast comparisons}

In this section we analyse the out-of-sample forecast performance using quarterly data from 1996Q1 to 2016Q1.16 Data on CPI inflation and inflation expectations are given in Figure 1. The unemployment rate and three month treasury bill rate are shown in Figure A1 in Appendix A. ${ }^{17}$

We compare the forecasting performance of the bivariate specification in equation (3) with the univariate specification in equation (2). In addition, we compare the forecasting performance of the fourvariate specification in equation (5) with the trivariate specification in equation (4). ${ }^{18}$ More specifically, the out-of-sample forecast exercise is conducted the following way: All models are first estimated for a training period of eight years, using data from 1996Q1 to 2003Q4.19 Forecasts one to twelve quarters ahead (2004Q1-2006Q4) are then generated and forecast errors are recorded. The sample is then extended one quarter, the models are re-estimated and new forecasts twelve quarters ahead are generated. This procedure stops at the end of the sample; the last forecasts are generated based on an estimation using data from 1996Q1 to 2015Q4. The forecast comparisons in this study are thus based on between 38 and 49 forecasts depending on the forecast horizon.

\footnotetext{
14 To our knowledge, no valid test exists to test the null hypothesis of equal forecasting performance in our setting. The problem is that we compare forecasts from nested models estimated with Bayesian methods at forecast horizons exceeding one.

15 However, if one wants to do scenario analysis - where the effect of one variable on another is of interest - it is not unreasonable to choose the model with a higher RMSFE. As an extreme example, consider the case where a univariate model has the smallest out-of-sample RMSFE. Of course, such a model can not tell us anything about what happens when other related variables vary.

16 The inflation target policy was declared in 1993 but it was not until 1996 that interest rates began to come down to more normal levels.

17 Note that the inflation expectations and the three month treasury bill rate are not revised. Hence, the latest vintage is equal to real-time data. Inflation and the unemployment rate are subject to minor revisions. The fact that we do not use real-time data for these variables should hence have only minor effects on our results. For a discussion concerning real-time data, see Croushore and Stark (2001)

18 The forecast precision of the individual categories of inflation expectations when they are not used in models (but simply used as predictors of future inflation as they are) are shown in Table A7 in Appendix C.

19 The numerical evaluation of the posterior distribution is conducted using the Gibbs sampler and the number of draws is set to 10000 .
} 
The differences in RMSFE for CPI-inflation between the univariate model and the bivariate ones are shown in Figure 2.20 A positive RMSFE difference signals that the particular inflation expectation series contributes to better out-ofsample forecasts.

Looking at the inflation expectations from the NIER's survey first, it can be noted that the two bivariate models with these included have lower RMSFEs than the univariate model at forecast horizons up to seven and eight quarters when household and business expectations are used respectively. The improvement in RMSFE peaks at the two to three-quarter horizons. The reduction in the RMSFE relative to the univariate model is larger when business expectations are used. However, improvements are typically small relative to the level of the RMSFE. Only at the three shortest horizons when using the business expectations can a reduction of the RMSFE of more than thirteen per cent be found; see Table A5 in Appendix C.

Figure 2. Reduction in RMSFE by adding inflation expectations to the univariate model of CPI-inflation

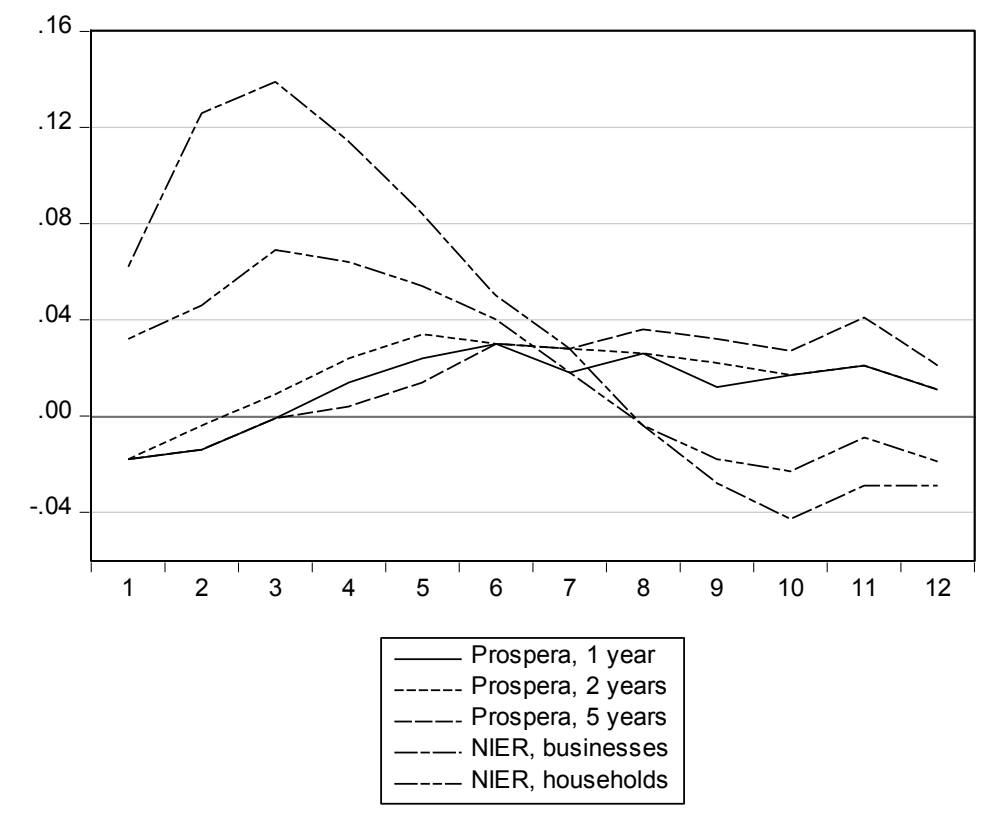

Note: Reduction in RMSFE is given in percentage points on the vertical axis. A positive number indicates that the model with inflation expectations has a lower RMSFE than the model without inflation expectations. Forecast horizon in quarters on the horizontal axis.

20 The RMSFEs of the different models are given in Tables A2 and A3 in Appendix C. Table A4 in Appendix $C$ gives the RMSFEs of two commonly used benchmarks, namely a naïve forecast and a recent mean forecast. 
When the inflation expectations of TNS Sifo Prospera are employed, we find that the results are similar regardless of whether the one-, two- or fiveyear inflation expectations are studied (see Figure 2). It can be noted though that the profile of the difference in RMSFEs is different to when the NIER's survey data were used. Forecast precision is actually reduced at short horizons. At horizons of four quarters or larger, the RMSFE is reduced when the inflation expectations are included in the model but the reduction in the RMSFE is very small; in no case is the RMSFE reduced by more than 0.04 percentage points.

The differences in RMSFEs between the trivariate model and fourvariate ones are shown in Figure 3. In general, we find that inflation expectations tend to Granger cause inflation; the RMSFEs of the fourvariate models are generally lower than that of the trivariate model. Similar to the comparison between the univariate and bivariate models above, we again find that the profile of the improvement in forecast precision differs depending on which survey has been used. The two series from the NIER's survey both reduce the RMSFE the most at the three-quarter horizon whereas the three series from the TNS Sifo Prospera survey appear to be most useful at longer horizons.

Comparing Figures 2 and 3, it can be seen that the three series from the TNS Sifo Prospera survey reduce the RMSFE approximately as much when moving from a trivariate to a fourvariate model as when moving from a univariate to a bivariate model. The largest improvement in forecast precision - when comparing the fourvariate models and the trivariate model over all horizons and inflation expectation series - is found at the threequarter horizon when the NIER's business expectations are used; the fourvariate model then has an RMSFE which is 0.12 percentage points lower than the trivariate model. This is a non-negligible improvement - corresponding to a nine per cent reduction in the RMSFE; see Table A6 in Appendix C. However, the results shown in Figure 3 do not point to quantitatively meaningful reductions in RMSFEs in general. 
Figure 3. Reduction in RMSFE by adding inflation expectations to the trivariate model of CPI-inflation

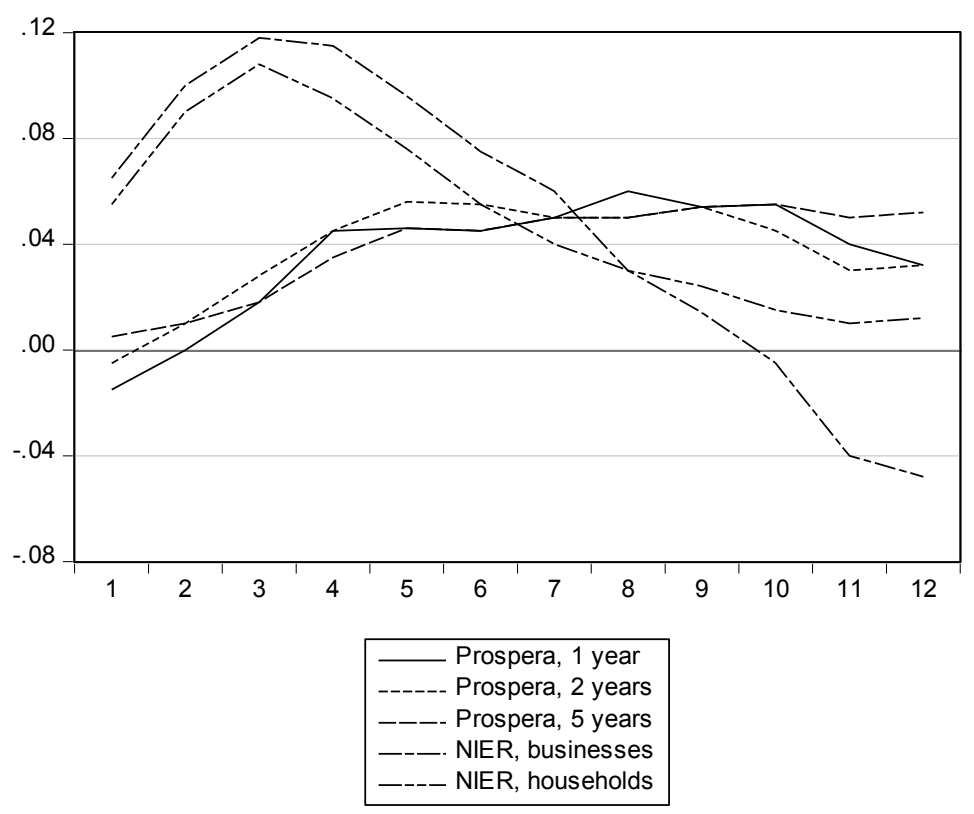

Note: Reduction in RMSFE is given in percentage points on the vertical axis. A positive number indicates that the model with inflation expectations has a lower RMSFE than the model without inflation expectations. Forecast horizon in quarters on the horizontal axis.

Summing up, we have found that adding inflation expectations to a model generally tends to reduce the RMSFE and, hence, that inflation expectations Granger cause inflation. However, the magnitude of the improvement is typically small and often not quantitatively meaningful. Our results are accordingly not very encouraging concerning the usefulness of the inflation expectations when it comes to improving the precision of VAR-based inflation forecasts in practice.

\section{Sensitivity analysis}

Bayesian estimation makes use of priors which can affect the conclusions. An easy and transparent way to assess the importance of the priors (and hyperparameters) is to simply abandon the Bayesian framework completely and conduct the exercises using a classical framework.

In this section we accordingly perform the same out-of-sample forecast exercise as that described in Section 4 but with the traditional VAR model

$\mathbf{G}(L) \mathbf{x}_{t}=\mathbf{c}+\boldsymbol{\eta}_{t}$, 
where $\mathbf{c}$ is an $n \times 1$ vector vector of intercepts; $\mathbf{G}(L), \mathbf{x}_{t}$ and $\boldsymbol{\eta}_{t}$ are all defined as above. The model is here estimated using classical methods, that is, the estimated parameters of (6) maximizes the likelihood function.

Results are shown in tables A10 to A13 in Appendix C and are generally in line with the results discussed in Section 4. The only meaningful improvement in RMSFE found is at short horizons when the expectations of businesses in the National Institute of Economic Research's Economic Tendency Survey are used. It can be noted that the RMSFEs of the bivariate classical VAR models are generally smaller than those of the bivariate BVAR models, a finding that perhaps is somewhat surprising given that the BVARs often are considered better forecasting tools than VARs estimated with classical methods. In addition, the reductions compared to the benchmark univariate model are typically bigger using classical VARs. However, the problems associated with overparameterisation do show up also in this study. For the larger VARs, forecast precision often deteriorates when inflation expectations are included in the model; see Tables A11 and A13 in Appendix $\mathrm{C}$ and compare them with the corresponding BVAR results in Tables A3 and A6.

\section{Conclusions}

In this paper, we have taken the forecaster's perspective on survey measures of inflation expectations and investigated whether inflation expectations in Sweden Granger cause Swedish CPI-inflation. This was done by studying the accuracy of out-of-sample forecasts from Bayesian VAR models. It was found that the inclusion of inflation expectations in the models tends to improve forecast precision. The improvement is typically very small though and does in general not seem economically relevant. One exception can possibly be found in the expectations of businesses in the National Institute of Economic Research's Economic Tendency Survey; when included in the models, these improve forecast precision at short horizons in a meaningful way. It accordingly appears that the survey measures of inflation expectations studied in this paper are of limited usefulness to those who try to improve VAR-based forecasts of Swedish CPI inflation. 
In order to achieve a quantitatively meaningful improvement, he or she should most likely look elsewhere.

That the inflation expectations do not seem particularly useful to VAR modellers does not mean that they are collected in vain though. From a policy perspective, survey expectations can still provide relevant information concerning, for example, the credibility of the inflation target or other challenges that a central bank might face when conducting monetary policy. 


\section{References}

Adam, K. and Padula, M. (2011), "Inflation Dynamics and Subjective Expectations in the United States", Economic Inquiry, 49, 13-25.

Adolfson, M., Andersson, M. K., Lindé, J., Villani, M. and Vredin, A. (2007), "Modern Forecasting Models in Action: Improving Macro Economic Analyses at Central Banks", International Journal of Central Banking 3, 111-144.

Ashley, R., Granger, C. W. J. and Schmalensee, R. (1980), "Advertising and Aggregate Consumption: An Analysis of Causality", Econometrica 48, 1149-1167.

Bachmeier, L. J., Leelahanon, S. and Li, Q. (2007), "Money Growth and Inflation in the United States", Macroeconomic Dynamics 11, 113-127.

Beechey, M., Johannsen, B. and Levin, A. (2011), “Are Long-Run Inflation Expectations Anchored More Firmly in the Euro Area Than in the United States?”, American Economic Journal: Macroeconomics, 3, 104-129.

Beechey, M. and Österholm, P. (2010), "Forecasting inflation in an inflation targeting regime: a role for informative steady-state priors", International Journal of Forecasting, 26, 248-264.

Berger, H. and Österholm, P. (2011), "Does Money Granger Cause Inflation in the Euro Area? Evidence from Out-of-Sample Forecasts Using Bayesian VARs", Economic Record 87, 45-60.

Canova, F. and Gambetti, L. (2010), "Do Expectations Matter? The Great Moderation Revisited", American Economic Journal: Macroeconomics 2, 183-205.

Christoffel, K., Coenen, G. and Warne, A. (2011), "Forecasting with DSGE Models". In: Clements, M. P. and Hendry, D. F. (eds), The Oxford Handbook of Economic Forecasting, Oxford University Press, Oxford.

Clark, T. E. and Davig, T. (2008), "An Empirical Assessment of the Relationships among Inflation and Short- and Long-Term Expectations", Research Working Paper 08-05, Federal Reserve Bank of Kansas City.

Cogley, T., and T. J. Sargent (2001), "Evolving Post-World War II U.S. Inflation Dynamics", NBER Macroeconomics Annual 16, 331-373.

Croushore, D. and Stark, T. (2001), "A Real-Time Data Set for Macroeconomists", Journal of Econometrics 105, 111-130.

Friedman, B. and Kuttner, K. (1993), "Another Look at the Evidence of Money-Income Causality", Journal of Econometrics 57, 189-203.

Fuhrer, J. (2012), "The Role of Expectations in Inflation Dynamics", International Journal of Central Banking 8, 137-165. 
Gavin, W. T. and Kliesen, K. L. (2008), "Forecasting Inflation and Output: Comparing Data-Rich Models with Simple Rules", Federal Reserve Bank of St Louis Review 90, 175-192.

Gürkaynak, R., Levin, A. T., Marder, A. N. and Swanson, E. T. (2007), "Inflation Targeting and the Anchoring of Inflation Expectations in the Western Hemisphere", Federal Reserve Bank of San Francisco Economic Review 2007, 25-47.

Lütkepohl, H. (2005), New Introduction to Multiple Time Series, Springer, Berlin.

Nunes, R. (2010), "Inflation Dynamics: The Role of Expectations", Joumal of Money, Credit and Banking, 42, 1161-1172.

Primiceri, G. (2005), "Time Varying Structural Vector Autoregressions and Monetary Policy”, Review of Economic Studies 72, 821-852.

Ribba, A. (2006), "The Joint Dynamics of Inflation, Unemployment and Interest Rate in the United States Since 1980", Empirical Economics 31, 497-511.

Scheufele, R. (2011), “Are Qualitative Inflation Expectations Useful to Predict Inflation?", Journal of Business Cycle Measurement and Analysis 2011/1, 29-53.

Stock, J. and Watson, M. (1989), "Interpreting the Evidence on MoneyIncome Causality", Journal of Econometrics 40, 161-181.

Sveriges Riksbank (2008), Separate Minutes of the Executive Board Meeting on 3 September 2008.

Us, V. (2004), "Inflation Dynamics and Monetary Policy Strategy: Some Prospects for the Turkish Economy", Journal of Policy Modeling, 26, 1003-1013.

Villani, M. (2009), "Steady-State Priors for Vector Autoregressions", Joumal of Applied Econometrics, 24, 630-650.

Wimanda, E. R., Turner, P. M. and Hall, M. J. B. (2011), "Expectations and the Inertia of Inflation: The Case of Indonesia", Joumal of Policy Modeling, 33, 426-438. 


\section{Appendix A - Data}

Figure A1. Unemployment rate and interest rate.
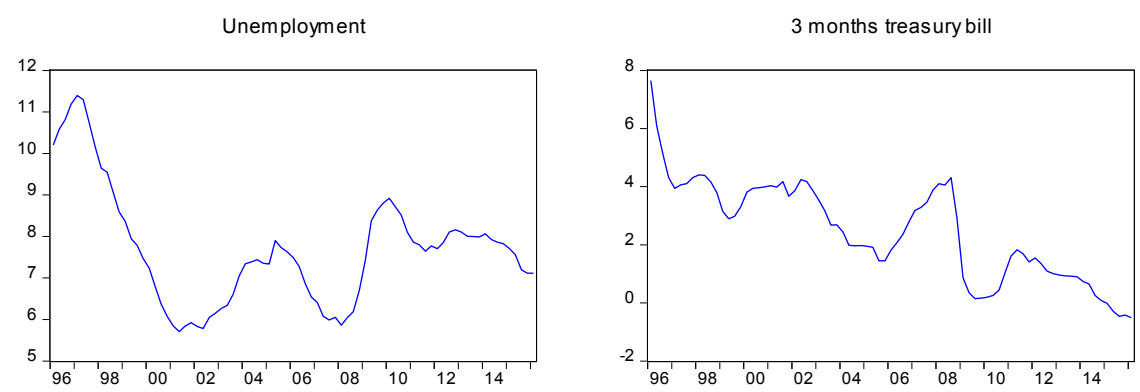

Note: Both variables are measured in per cent.

Figure A2. Inflation expectations, TNS Sifo Prospera, Money market players

TNS Sifo Prospera, Money market players, 1 year

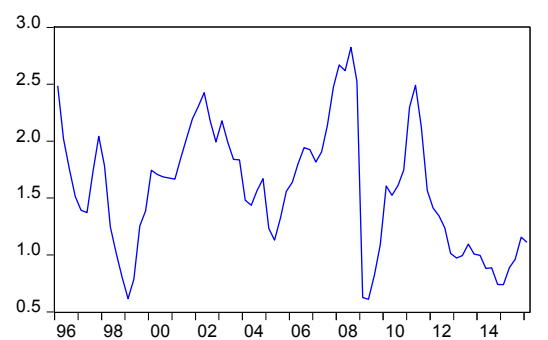

TNS Sifo Prospera, Money market players, 5 years

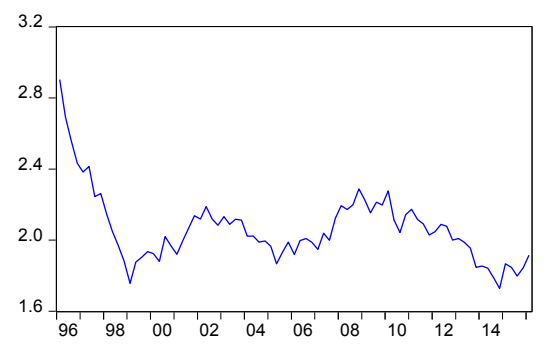

TNS Sifo Prospera, Money market players, 2 years

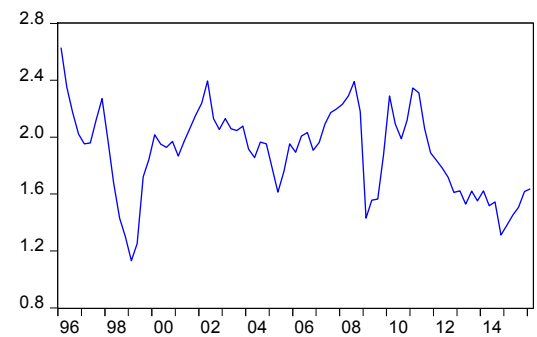




\section{Appendix B - Steady-state priors}

Table A1. Steady-state priors.

\begin{tabular}{lc} 
Variable & Prior interval \\
$u_{t}$ & $(5.0 ; 8.0)$ \\
$\pi_{t}$ & $(1.0 ; 3.0)$ \\
$i_{t}$ & $(3.0 ; 5.0)$ \\
$\pi_{t}^{e}$ & $(1.0 ; 3.0)$ \\
\hline
\end{tabular}

Note: Ninety-five per cent prior probability intervals for parameters determining the unconditional means. Prior distributions are all assumed to be normal. Variables are defined in equations (3) and (5). 


\section{Appendix $\mathrm{C}-\mathrm{RMSFEs}$ and relative RMSFEs}

Table A2. RMSFEs of univariate and bivariate models.

\begin{tabular}{|c|c|c|c|c|c|c|}
\hline \multirow[b]{2}{*}{ Horizon } & \multirow[b]{2}{*}{ Univariate } & \multicolumn{5}{|c|}{ Bivariate models } \\
\hline & & $\begin{array}{c}\text { Prospera, } \\
1 \text { year }\end{array}$ & $\begin{array}{c}\text { Prospera, } \\
2 \text { years }\end{array}$ & $\begin{array}{c}\text { Prospera, } \\
5 \text { years }\end{array}$ & $\begin{array}{c}\text { NIER, } \\
\text { businesses }\end{array}$ & $\begin{array}{c}\text { NIER, } \\
\text { households }\end{array}$ \\
\hline $1 Q$ & 0.59 & 0.61 & 0.61 & 0.61 & 0.53 & 0.56 \\
\hline $2 Q$ & 0.99 & 1.00 & 0.99 & 1.00 & 0.86 & 0.94 \\
\hline 3Q & 1.28 & 1.28 & 1.27 & 1.28 & 1.14 & 1.21 \\
\hline 4Q & 1.48 & 1.47 & 1.46 & 1.48 & 1.37 & 1.42 \\
\hline 5Q & 1.57 & 1.55 & 1.54 & 1.56 & 1.49 & 1.52 \\
\hline 6Q & 1.59 & 1.56 & 1.56 & 1.56 & 1.54 & 1.55 \\
\hline 7Q & 1.58 & 1.56 & 1.55 & 1.55 & 1.55 & 1.56 \\
\hline 8Q & 1.56 & 1.53 & 1.53 & 1.52 & 1.56 & 1.56 \\
\hline $9 Q$ & 1.52 & 1.51 & 1.50 & 1.49 & 1.55 & 1.54 \\
\hline 10Q & 1.50 & 1.48 & 1.48 & 1.47 & 1.54 & 1.52 \\
\hline 11Q & 1.48 & 1.46 & 1.46 & 1.44 & 1.51 & 1.49 \\
\hline $12 Q$ & 1.47 & 1.46 & 1.46 & 1.45 & 1.50 & 1.49 \\
\hline
\end{tabular}

Table A3. RMSFEs of trivariate and fourvariate models.

\begin{tabular}{|c|c|c|c|c|c|c|}
\hline \multirow[b]{2}{*}{ Horizon } & \multirow[b]{2}{*}{ Trivariate } & \multicolumn{5}{|c|}{ Fourvariate models } \\
\hline & & $\begin{array}{c}\text { Prospera, } \\
1 \text { year }\end{array}$ & $\begin{array}{c}\text { Prospera, } \\
2 \text { years }\end{array}$ & $\begin{array}{c}\text { Prospera, } \\
5 \text { years }\end{array}$ & $\begin{array}{c}\text { NIER, } \\
\text { businesses }\end{array}$ & $\begin{array}{c}\text { NIER, } \\
\text { households }\end{array}$ \\
\hline $1 Q$ & 0.62 & 0.63 & 0.62 & 0.61 & 0.55 & 0.56 \\
\hline $2 Q$ & 1.02 & 1.02 & 1.01 & 1.01 & 0.92 & 0.93 \\
\hline $3 Q$ & 1.33 & 1.31 & 1.30 & 1.31 & 1.21 & 1.22 \\
\hline 4Q & 1.55 & 1.50 & 1.50 & 1.51 & 1.43 & 1.45 \\
\hline $5 Q$ & 1.66 & 1.61 & 1.60 & 1.61 & 1.56 & 1.58 \\
\hline $6 Q$ & 1.71 & 1.66 & 1.65 & 1.66 & 1.63 & 1.65 \\
\hline 7Q & 1.73 & 1.68 & 1.68 & 1.68 & 1.67 & 1.69 \\
\hline $8 \mathbf{Q}$ & 1.73 & 1.67 & 1.68 & 1.68 & 1.70 & 1.70 \\
\hline $9 Q$ & 1.71 & 1.66 & 1.66 & 1.66 & 1.70 & 1.69 \\
\hline $10 Q$ & 1.69 & 1.63 & 1.64 & 1.63 & 1.69 & 1.67 \\
\hline 11Q & 1.64 & 1.60 & 1.61 & 1.59 & 1.68 & 1.63 \\
\hline $12 Q$ & 1.60 & 1.57 & 1.57 & 1.55 & 1.65 & 1.59 \\
\hline
\end{tabular}

Table A4. RMSFEs of alternative forecasts.

\begin{tabular}{l|cc} 
Horizon & $\begin{array}{c}\text { Naïve } \\
\text { forecast }\end{array}$ & $\begin{array}{c}\text { Recent } \\
\text { mean } \\
\text { forecast }\end{array}$ \\
$\mathbf{1 Q}$ & 0.65 & 1.43 \\
$\mathbf{2 Q}$ & 1.10 & 1.50 \\
$\mathbf{3 Q}$ & 1.47 & 1.55 \\
$\mathbf{4 Q}$ & 1.77 & 1.57 \\
$\mathbf{5 Q}$ & 1.96 & 1.58 \\
$\mathbf{6 Q}$ & 2.07 & 1.56 \\
$\mathbf{7 Q}$ & 2.15 & 1.53 \\
$\mathbf{8 Q}$ & 2.16 & 1.48 \\
$\mathbf{9 Q}$ & 2.12 & 1.44 \\
$\mathbf{1 0 Q}$ & 2.06 & 1.40 \\
$\mathbf{1 1 Q}$ & 1.98 & 1.39 \\
$\mathbf{1 2 Q}$ & 1.91 & 1.40 \\
\hline
\end{tabular}

Note: The recent mean forecasts are based on the mean of the last twelve observations preceding the forecast date. 
Table A5. RMSFEs of the univariate model and relative RMSFEs of the bivariate models.

\begin{tabular}{l|c|ccccc} 
Horizon & $\begin{array}{c}\text { Univariate } \\
\text { RMSFEs }\end{array}$ & $\begin{array}{c}\text { Prospera, } \\
\text { 1 year }\end{array}$ & $\begin{array}{c}\text { Prospera, } \\
\text { 2 years }\end{array}$ & $\begin{array}{c}\text { Prospera, } \\
\text { 5 years }\end{array}$ & $\begin{array}{c}\text { NIER, } \\
\text { businesses }\end{array}$ & $\begin{array}{c}\text { NIER, } \\
\text { households }\end{array}$ \\
$\mathbf{1 Q}$ & 0.59 & 1.03 & 1.03 & 1.03 & 0.90 & 0.95 \\
$\mathbf{2 Q}$ & 0.99 & 1.01 & 1.00 & 1.01 & 0.87 & 0.95 \\
$\mathbf{3 Q}$ & 1.28 & 1.00 & 0.99 & 1.00 & 0.89 & 0.95 \\
$\mathbf{4 Q}$ & 1.48 & 0.99 & 0.98 & 1.00 & 0.92 & 0.96 \\
$\mathbf{5 Q}$ & 1.57 & 0.98 & 0.98 & 0.99 & 0.95 & 0.97 \\
$\mathbf{6 Q}$ & 1.59 & 0.98 & 0.98 & 0.98 & 0.97 & 0.97 \\
$\mathbf{7 Q}$ & 1.58 & 0.99 & 0.98 & 0.98 & 0.98 & 0.99 \\
$\mathbf{8 Q}$ & 1.56 & 0.98 & 0.98 & 0.98 & 1.00 & 1.00 \\
$\mathbf{9 Q}$ & 1.52 & 0.99 & 0.99 & 0.98 & 1.02 & 1.01 \\
$\mathbf{1 0 Q}$ & 1.50 & 0.99 & 0.99 & 0.98 & 1.03 & 1.02 \\
$\mathbf{1 1 Q}$ & 1.48 & 0.99 & 0.99 & 0.97 & 1.02 & 1.01 \\
$\mathbf{1 2 Q}$ & 1.47 & 0.99 & 0.99 & 0.99 & 1.02 & 1.01 \\
\hline
\end{tabular}

Note: The relative RMSFE is defined as the RMSFE of the bivariate model divided by the RMSFE of the univariate model. A value smaller than one accordingly implies that the RMSFE of the bivariate model is smaller than that of the univariate model.

Table A6. RMSFEs of the trivariate model and relative RMSFEs of the fourvariate models.

\begin{tabular}{|c|c|c|c|c|c|c|}
\hline \multirow[b]{2}{*}{ Horizon } & \multirow[b]{2}{*}{$\begin{array}{l}\text { Trivariate } \\
\text { RMSFEs }\end{array}$} & \multicolumn{5}{|c|}{ Fourvariate models (relative RMSFEs) } \\
\hline & & $\begin{array}{c}\text { Prospera, } \\
1 \text { year }\end{array}$ & $\begin{array}{c}\text { Prospera, } \\
2 \text { years }\end{array}$ & $\begin{array}{c}\text { Prospera, } \\
5 \text { years }\end{array}$ & $\begin{array}{c}\text { NIER, } \\
\text { businesses }\end{array}$ & $\begin{array}{c}\text { NIER, } \\
\text { households }\end{array}$ \\
\hline 1Q & 0.62 & 1.02 & 1.01 & 0.99 & 0.89 & 0.91 \\
\hline $2 \mathbf{Q}$ & 1.02 & 1.00 & 0.99 & 0.99 & 0.90 & 0.91 \\
\hline $3 \mathbf{Q}$ & 1.33 & 0.99 & 0.98 & 0.99 & 0.91 & 0.92 \\
\hline 4Q & 1.55 & 0.97 & 0.97 & 0.98 & 0.93 & 0.94 \\
\hline $5 \mathbf{Q}$ & 1.66 & 0.97 & 0.97 & 0.97 & 0.94 & 0.95 \\
\hline 6Q & 1.71 & 0.97 & 0.97 & 0.97 & 0.96 & 0.97 \\
\hline 7Q & 1.73 & 0.97 & 0.97 & 0.97 & 0.97 & 0.98 \\
\hline $\mathbf{8 Q}$ & 1.73 & 0.97 & 0.97 & 0.97 & 0.98 & 0.98 \\
\hline 9Q & 1.71 & 0.97 & 0.97 & 0.97 & 0.99 & 0.99 \\
\hline 10Q & 1.69 & 0.97 & 0.97 & 0.97 & 1.00 & 0.99 \\
\hline 11Q & 1.64 & 0.98 & 0.98 & 0.97 & 1.02 & 0.99 \\
\hline $12 Q$ & 1.60 & 0.98 & 0.98 & 0.97 & 1.03 & 0.99 \\
\hline
\end{tabular}

Note: The relative RMSFE is defined as the RMSFE of the fourvariate model divided by the RMSFE of the trivariate model. A value smaller than one accordingly implies that the RMSFE of the fourvariate model is smaller than that of the trivariate model.

Table A7. RMSFEs of inflation expectations

\begin{tabular}{|c|c|c|c|c|c|c|c|c|}
\hline Horizon & $\begin{array}{l}\text { Pros- } \\
\text { pera, } 1 \\
\text { year }\end{array}$ & $\begin{array}{c}\text { Pros- } \\
\text { pera, } 2 \\
\text { years }\end{array}$ & $\begin{array}{c}\text { Pros- } \\
\text { pera, } 5 \\
\text { years }\end{array}$ & $\begin{array}{l}\text { Pros- } \\
\text { pera } \\
\text { MMP, } \\
1 \text { year }\end{array}$ & $\begin{array}{l}\text { Pros- } \\
\text { pera } \\
\text { MMP, } 2 \\
\text { years }\end{array}$ & $\begin{array}{l}\text { Pros- } \\
\text { pera } \\
\text { MMP, } 5 \\
\text { years }\end{array}$ & $\begin{array}{c}\text { NIER, } \\
\text { busi- } \\
\text { nesses }\end{array}$ & $\begin{array}{l}\text { NIER, } \\
\text { house } \\
\text { holds }\end{array}$ \\
\hline $1 Q$ & 1.01 & 1.29 & 1.61 & 0.95 & 1.36 & 1.61 & 0.92 & 1.26 \\
\hline $2 Q$ & 1.18 & 1.37 & 1.64 & 1.08 & 1.39 & 1.62 & 0.90 & 1.35 \\
\hline $3 Q$ & 1.38 & 1.48 & 1.68 & 1.26 & 1.44 & 1.64 & 1.00 & 1.46 \\
\hline $4 Q$ & 1.54 & 1.58 & 1.72 & 1.41 & 1.50 & 1.65 & 1.17 & 1.61 \\
\hline $5 Q$ & 1.62 & 1.64 & 1.73 & 1.50 & 1.54 & 1.65 & 1.33 & 1.71 \\
\hline $6 Q$ & 1.69 & 1.68 & 1.74 & 1.57 & 1.57 & 1.65 & 1.44 & 1.78 \\
\hline $7 Q$ & 1.74 & 1.73 & 1.76 & 1.63 & 1.61 & 1.66 & 1.53 & 1.84 \\
\hline $8 Q$ & 1.74 & 1.75 & 1.76 & 1.65 & 1.64 & 1.67 & 1.63 & 1.91 \\
\hline $9 Q$ & 1.72 & 1.75 & 1.78 & 1.65 & 1.66 & 1.68 & 1.68 & 1.93 \\
\hline $10 Q$ & 1.69 & 1.75 & 1.80 & 1.63 & 1.67 & 1.71 & 1.70 & 1.94 \\
\hline $11 Q$ & 1.65 & 1.74 & 1.81 & 1.61 & 1.68 & 1.73 & 1.67 & 1.95 \\
\hline $12 Q$ & 1.62 & 1.74 & 1.83 & 1.59 & 1.70 & 1.76 & 1.62 & 1.95 \\
\hline
\end{tabular}

Note: The RMSFEs have been calculated by comparing the expectation with the actual value at each horizon (regardless of the intended horizon of the inflation expectations). MMP=money market players. 
Figure A3. Reduction in RMSFE by adding inflation expectations to the univariate model of CPI-inflation - Money market players

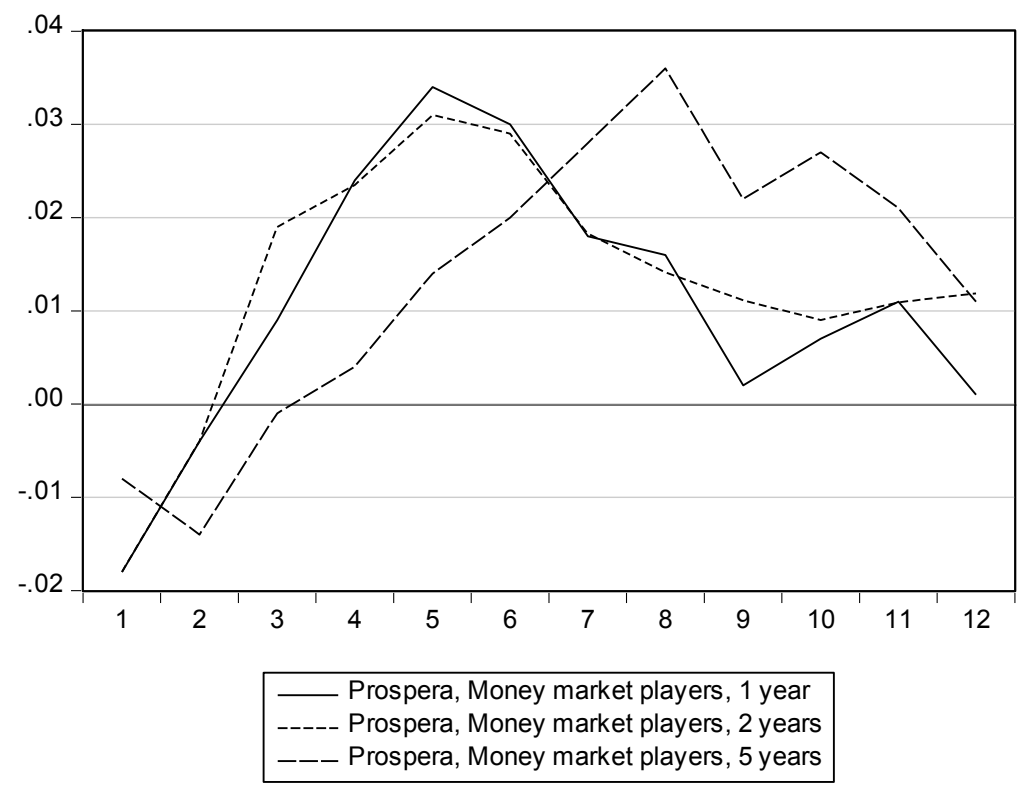

Note: Reduction in RMSFE given in percentage points on the vertical axis. A positive number indicates that the model with inflation expectations has a lower RMSFE than the model without inflation expectations. Forecast horizon in quarters on the horizontal axis.

Figure A4. Reduction in RMSFE by adding inflation expectations to the trivariate model of CPI-inflation - Money market players

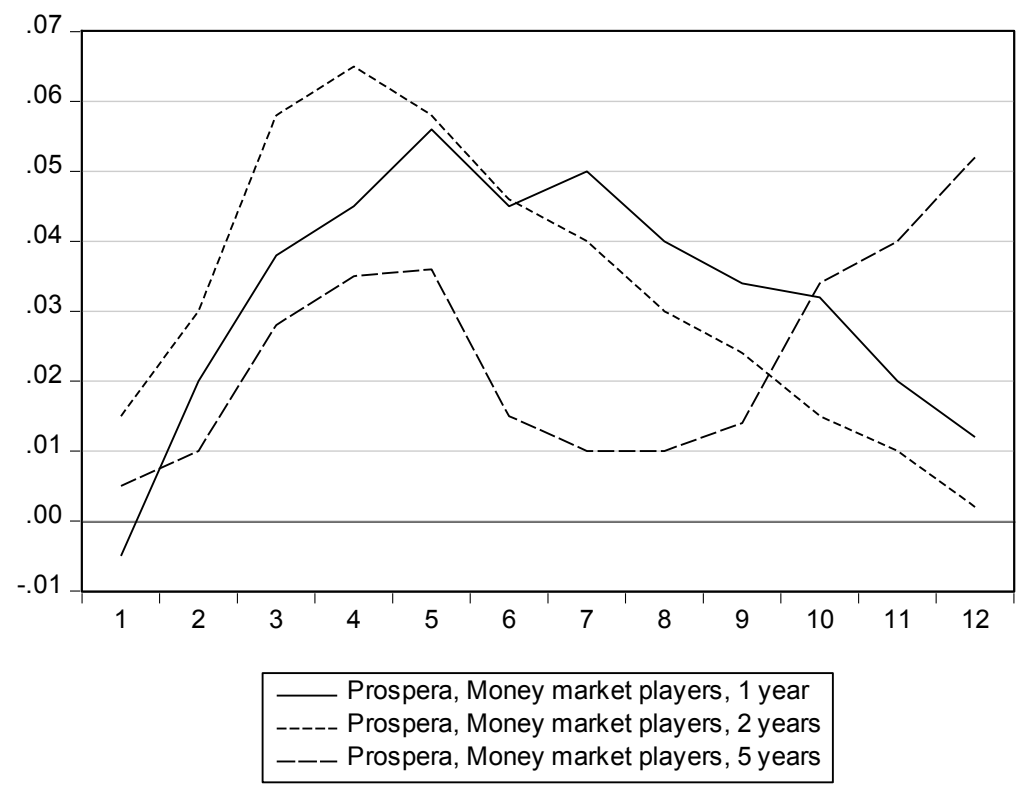

Note: Reduction in RMSFE given in percentage points on the vertical axis. A positive number indicates that the model with inflation expectations has a lower RMSFE than the model without inflation expectations. Forecast horizon in quarters on the horizontal axis. 
Table A8. RMSFEs of univariate and bivariate models - Money market players.

\begin{tabular}{|l|c|ccc|} 
& & \multicolumn{3}{c|}{ Bivariate models } \\
Horizon & Univariate & $\begin{array}{c}\text { Prospera, } \\
\text { 1 year }\end{array}$ & $\begin{array}{c}\text { Prospera, } \\
\text { 2 years }\end{array}$ & $\begin{array}{c}\text { Prospera, } \\
5 \text { years }\end{array}$ \\
\hline $\mathbf{1 Q}$ & 0.59 & 0.61 & 0.61 & 0.60 \\
$\mathbf{2 Q}$ & 0.99 & 0.99 & 0.99 & 1.00 \\
$\mathbf{3 Q}$ & 1.28 & 1.27 & 1.26 & 1.28 \\
$\mathbf{4 Q}$ & 1.48 & 1.46 & 1.46 & 1.48 \\
$\mathbf{5 Q}$ & 1.57 & 1.54 & 1.54 & 1.56 \\
$\mathbf{6 Q}$ & 1.59 & 1.56 & 1.56 & 1.57 \\
$\mathbf{7 Q}$ & 1.58 & 1.56 & 1.56 & 1.55 \\
$\mathbf{8 Q}$ & 1.56 & 1.54 & 1.54 & 1.52 \\
$\mathbf{9 Q}$ & 1.52 & 1.52 & 1.51 & 1.50 \\
$\mathbf{1 0 Q}$ & 1.50 & 1.49 & 1.49 & 1.47 \\
$\mathbf{1 1 Q}$ & 1.48 & 1.47 & 1.47 & 1.46 \\
$\mathbf{1 2 Q}$ & 1.47 & 1.47 & 1.46 & 1.46 \\
\hline
\end{tabular}

Table A9. RMSFEs of trivariate and fourvariate models - Money market players.

\begin{tabular}{l|c|ccc|} 
& & \multicolumn{3}{|c}{ Fourvariate models } \\
Horizon & Trivariate & $\begin{array}{c}\text { Prospera, } \\
\text { 1 year }\end{array}$ & $\begin{array}{c}\text { Prospera, } \\
\text { 2 years }\end{array}$ & $\begin{array}{c}\text { Prospera, } \\
5 \text { years }\end{array}$ \\
\hline $\mathbf{1 Q}$ & & 0.62 & 0.60 & 0.61 \\
$\mathbf{2 Q}$ & 0.62 & 1.00 & 0.99 & 1.01 \\
$\mathbf{3 Q}$ & 1.02 & 1.29 & 1.27 & 1.30 \\
$\mathbf{4 Q}$ & 1.33 & 1.50 & 1.48 & 1.51 \\
$\mathbf{5 Q}$ & 1.55 & 1.60 & 1.60 & 1.62 \\
$\mathbf{6 Q}$ & 1.66 & 1.66 & 1.66 & 1.69 \\
$\mathbf{7 Q}$ & 1.71 & 1.68 & 1.69 & 1.72 \\
$\mathbf{8 Q}$ & 1.73 & 1.69 & 1.70 & 1.72 \\
$\mathbf{9 Q}$ & 1.73 & 1.68 & 1.69 & 1.70 \\
$\mathbf{1 0 Q}$ & 1.71 & 1.65 & 1.67 & 1.65 \\
$\mathbf{1 1 Q}$ & 1.69 & 1.62 & 1.63 & 1.60 \\
$\mathbf{1 2 Q}$ & 1.64 & 1.59 & 1.60 & 1.55 \\
\hline
\end{tabular}


Table A10. RMSFEs of univariate and bivariate models - OLS estimation.

\begin{tabular}{|c|c|c|c|c|c|c|}
\hline \multirow[b]{2}{*}{ Horizon } & \multirow[b]{2}{*}{ Univariate } & \multicolumn{5}{|c|}{ Bivariate models } \\
\hline & & $\begin{array}{c}\text { Prospera, } \\
1 \text { year }\end{array}$ & $\begin{array}{c}\text { Prospera, } \\
2 \text { years }\end{array}$ & $\begin{array}{c}\text { Prospera, } \\
5 \text { years }\end{array}$ & $\begin{array}{c}\text { NIER, } \\
\text { businesses }\end{array}$ & $\begin{array}{c}\text { NIER, } \\
\text { households }\end{array}$ \\
\hline 1Q & 0.56 & 0.62 & 0.57 & 0.50 & 0.50 & 0.54 \\
\hline $2 Q$ & 0.97 & 0.95 & 0.90 & 0.90 & 0.76 & 0.97 \\
\hline 3Q & 1.24 & 1.27 & 1.21 & 1.24 & 1.01 & 1.24 \\
\hline 4Q & 1.44 & 1.52 & 1.43 & 1.47 & 1.27 & 1.43 \\
\hline 5Q & 1.50 & 1.59 & 1.50 & 1.54 & 1.44 & 1.57 \\
\hline 6Q & 1.48 & 1.58 & 1.50 & 1.53 & 1.49 & 1.65 \\
\hline 7Q & 1.44 & 1.54 & 1.47 & 1.48 & 1.47 & 1.66 \\
\hline 8Q & 1.41 & 1.51 & 1.45 & 1.44 & 1.46 & 1.59 \\
\hline 9Q & 1.39 & 1.46 & 1.43 & 1.41 & 1.45 & 1.50 \\
\hline $10 Q$ & 1.40 & 1.40 & 1.41 & 1.40 & 1.43 & 1.47 \\
\hline 11Q & 1.41 & 1.40 & 1.40 & 1.40 & 1.43 & 1.49 \\
\hline $12 Q$ & 1.42 & 1.38 & 1.40 & 1.41 & 1.44 & 1.50 \\
\hline
\end{tabular}

Table A11. RMSFEs of trivariate and fourvariate models - OLS estimation.

\begin{tabular}{|c|c|c|c|c|c|c|}
\hline \multirow[b]{2}{*}{ Horizon } & \multirow[b]{2}{*}{ Trivariate } & \multicolumn{5}{|c|}{ Fourvariate models } \\
\hline & & $\begin{array}{c}\text { Prospera, } \\
1 \text { year }\end{array}$ & $\begin{array}{c}\text { Prospera, } \\
2 \text { years }\end{array}$ & $\begin{array}{c}\text { Prospera, } \\
5 \text { years }\end{array}$ & $\begin{array}{c}\text { NIER, } \\
\text { businesses }\end{array}$ & $\begin{array}{c}\text { NIER, } \\
\text { households }\end{array}$ \\
\hline $1 Q$ & 0.61 & 0.76 & 0.68 & 0.59 & 0.58 & 0.63 \\
\hline $2 Q$ & 1.10 & 1.26 & 1.15 & 1.09 & 0.98 & 1.12 \\
\hline $3 Q$ & 1.49 & 1.59 & 1.52 & 1.46 & 1.29 & 1.46 \\
\hline $4 Q$ & 1.80 & 1.90 & 1.86 & 1.74 & 1.58 & 1.77 \\
\hline $5 Q$ & 1.86 & 1.88 & 1.89 & 1.78 & 1.78 & 1.89 \\
\hline $6 Q$ & 1.78 & 1.74 & 1.71 & 1.74 & 1.82 & 1.87 \\
\hline $7 Q$ & 1.73 & 1.72 & 1.66 & 1.78 & 1.85 & 1.84 \\
\hline $8 Q$ & 1.72 & 1.77 & 1.68 & 1.83 & 2.01 & 1.84 \\
\hline $9 Q$ & 1.75 & 1.84 & 1.76 & 1.86 & 2.17 & 1.78 \\
\hline $10 Q$ & 1.84 & 2.03 & 1.92 & 1.88 & 2.30 & 1.75 \\
\hline $11 Q$ & 1.87 & 2.09 & 2.01 & 1.92 & 2.39 & 1.74 \\
\hline $12 Q$ & 1.83 & 2.07 & 2.02 & 1.90 & 2.41 & 1.74 \\
\hline
\end{tabular}


Table A12. RMSFEs of the univariate model and relative RMSFEs of the bivariate models - OLS estimation.

\begin{tabular}{|c|c|c|c|c|c|c|}
\hline \multirow[b]{2}{*}{ Horizon } & \multirow[b]{2}{*}{$\begin{array}{l}\text { Univariate } \\
\text { RMSFEs }\end{array}$} & \multicolumn{5}{|c|}{ Bivariate models (relative RMSFEs) } \\
\hline & & $\begin{array}{c}\text { Prospera, } \\
1 \text { year }\end{array}$ & $\begin{array}{c}\text { Prospera, } \\
2 \text { years }\end{array}$ & $\begin{array}{c}\text { Prospera, } \\
5 \text { years }\end{array}$ & $\begin{array}{c}\text { NIER, } \\
\text { businesses }\end{array}$ & $\begin{array}{c}\text { NIER, } \\
\text { households }\end{array}$ \\
\hline 1Q & 0.56 & 1.11 & 1.02 & 0.89 & 0.89 & 0.96 \\
\hline $2 Q$ & 0.97 & 0.98 & 0.93 & 0.93 & 0.79 & 1.01 \\
\hline 3Q & 1.24 & 1.03 & 0.98 & 1.00 & 0.82 & 1.00 \\
\hline 4Q & 1.44 & 1.06 & 1.00 & 1.02 & 0.89 & 1.00 \\
\hline 5Q & 1.50 & 1.06 & 1.00 & 1.03 & 0.96 & 1.05 \\
\hline 6Q & 1.48 & 1.07 & 1.01 & 1.04 & 1.01 & 1.12 \\
\hline $7 Q$ & 1.44 & 1.07 & 1.02 & 1.03 & 1.02 & 1.15 \\
\hline $8 Q$ & 1.41 & 1.07 & 1.03 & 1.02 & 1.04 & 1.13 \\
\hline $9 Q$ & 1.39 & 1.05 & 1.03 & 1.01 & 1.04 & 1.08 \\
\hline $10 Q$ & 1.40 & 1.00 & 1.01 & 1.00 & 1.03 & 1.05 \\
\hline 11Q & 1.41 & 0.99 & 0.99 & 0.99 & 1.02 & 1.06 \\
\hline $12 Q$ & 1.42 & 0.97 & 0.98 & 0.99 & 1.01 & 1.05 \\
\hline
\end{tabular}

Note: The relative RMSFE is defined as the RMSFE of the bivariate model divided by the RMSFE of the univariate model. A value smaller than one accordingly implies that the RMSFE of the bivariate model is smaller than that of the univariate model.

Table A13. RMSFEs of the trivariate model and relative RMSFEs of the fourvariate models - OLS estimation.

\begin{tabular}{|c|c|c|c|c|c|c|}
\hline \multirow[b]{2}{*}{ Horizon } & \multirow[b]{2}{*}{$\begin{array}{c}\text { Trivariate } \\
\text { RMSFEs }\end{array}$} & \multicolumn{5}{|c|}{ Fourvariate models (relative RMSFEs) } \\
\hline & & $\begin{array}{c}\text { Prospera, } \\
1 \text { year }\end{array}$ & $\begin{array}{c}\text { Prospera, } \\
2 \text { years }\end{array}$ & $\begin{array}{c}\text { Prospera, } \\
5 \text { years }\end{array}$ & $\begin{array}{c}\text { NIER, } \\
\text { businesses }\end{array}$ & $\begin{array}{c}\text { NIER, } \\
\text { households }\end{array}$ \\
\hline $1 Q$ & 0.61 & 1.25 & 1.12 & 0.97 & 0.95 & 1.04 \\
\hline $2 \mathbf{Q}$ & 1.10 & 1.15 & 1.05 & 0.99 & 0.89 & 1.02 \\
\hline 3Q & 1.49 & 1.07 & 1.02 & 0.98 & 0.86 & 0.98 \\
\hline $4 Q$ & 1.80 & 1.06 & 1.03 & 0.97 & 0.88 & 0.98 \\
\hline 5Q & 1.86 & 1.01 & 1.02 & 0.96 & 0.96 & 1.02 \\
\hline 6Q & 1.78 & 0.98 & 0.96 & 0.98 & 1.02 & 1.05 \\
\hline $7 Q$ & 1.73 & 0.99 & 0.96 & 1.03 & 1.07 & 1.06 \\
\hline $8 Q$ & 1.72 & 1.03 & 0.97 & 1.06 & 1.17 & 1.07 \\
\hline $9 Q$ & 1.75 & 1.05 & 1.01 & 1.06 & 1.24 & 1.02 \\
\hline $10 Q$ & 1.84 & 1.10 & 1.04 & 1.02 & 1.25 & 0.95 \\
\hline $11 Q$ & 1.87 & 1.12 & 1.07 & 1.02 & 1.28 & 0.93 \\
\hline $12 Q$ & 1.83 & 1.13 & 1.10 & 1.04 & 1.32 & 0.95 \\
\hline
\end{tabular}

Note: The relative RMSFE is defined as the RMSFE of the fourvariate model divided by the RMSFE of the trivariate model. A value smaller than one accordingly implies that the RMSFE of the fourvariate model is smaller than that of the trivariate model. 

National Institute of Economic Research, Kungsgatan 12-14, Box 3116, SE-103 62 Stockholm, Sweden +4684535900, registrator@konj.se, www.konj.se/en

ISSN 1100-7818 